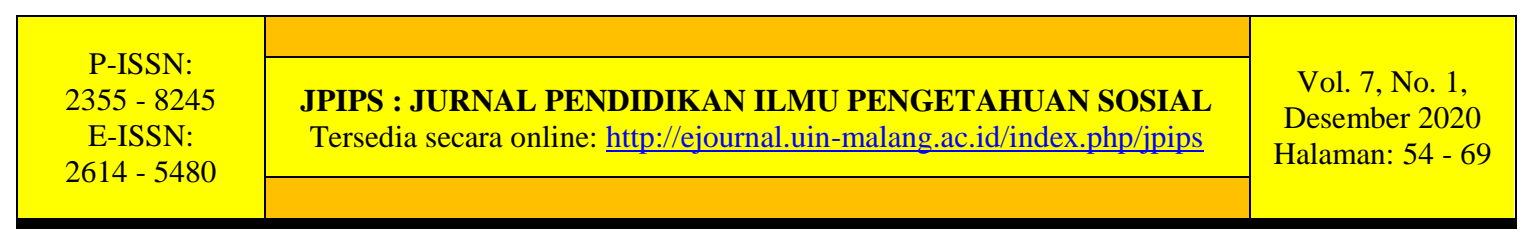

\title{
PEMBENTUKAN SIKAP SOSIAL SISWA MELALUI PEMBELAJARAN IPS DI SMP BRAWIJAYA SMART SCHOOL MALANG
}

\author{
Mohammad Miftahusya'ian', Wiwin Nuris Fitriana² dan Galih Puji Mulyoto \\ ${ }_{1,2,3}$ UIN Maulana Malik Ibrahim Malang \\ 1 pak.miftahusyaian@gmail.com, ${ }^{2}$ wiwinnuris062@gmail.com, \\ 3 galihpujimulyoto@uin-malang.ac.id
}

Diterima: 12-10-2020.; Direvisi: 18-12-2020; Disetujui: 22-12-2020

Permalink/DOI: 10.1886/jpips.v7i1.10485

\begin{abstract}
Abstrak: Tujuan penelitian ini adalah untuk: (1) mendeskripsikan proses pembentukan sikap sosial siswa melalui metode-metode pembelajaran IPS kelas VII SMP Brawijaya Smart School Malang, (2) mendeskripsikan bentuk-bentuk sikap sosial siswa yang dibentuk melalui metodemetode pembelajaran IPS kelas VII SMP Brawijaya Smart School Malang, (3) mendeskripsikan perubahan sikap sosial siswa setelah terjadi proses pembentukan sikap sosial melalui metodemetode pembelajaran IPS kelas VII SMP Brawijaya Smart School Malang. Penelitian ini menggunakan pendekatan penelitian kualitatif dengan jenis penelitian kualitatif deskriptif. Metode pengumpulan data yang dipakai yakni observasi, wawancara, dan dokumentasi. Penulis berperan menjadi pengamat dalam observasi. Dalam penelitian ini peneliti melakukan analisis data melalui reduksi data, penyajian data dan verifikasi (penarikan kesimpulan). Hasil penelitian menunjukkan bahwa, (1) proses pembentukan sikap sosial siswa kelas VII SMP Brawijaya Smart School Malang melalui metode-metode pembelajaran IPS dilakukan oleh guru dengan melibatkan dua faktor yakni faktor intern (siswa) dan faktor ekstern (lingkungan sekolah, rumah, dan masyarakat), (2) bentuk-bentuk sikap sosial siswa dapat terlihat dengan adanya kegiatan dikelas dan diluar kelas (kegiatan ekstrakulikuler) serta budaya dan peraturan sekolah, dan budaya sekolah (3) secara keseluruhan dari beberapa sikap sosial siswa yang mengalami perubahan yang paling terlihat yakni perubahannya pada sikap santun dan sikap disiplin.
\end{abstract}

\section{Kata Kunci: Sikap Sosial; Metode Pembelajaran IPS}

Abstract: The objectives of this study were to: (1) describe the process of forming students' social attitudes through social studies learning methods for class VII SMP Brawijaya Smart School Malang, (2) describe forms of student social attitudes formed through social studies learning methods for class VII SMP Brawijaya Smart School Malang, (3) describes the change in students' social attitudes after the process of forming social attitudes through social studies learning methods for class VII SMP Brawijaya Smart School Malang. This research uses a qualitative research approach with a descriptive qualitative research type. The data collection methods used were observation, interview, and documentation. The author acts as an observer in observation. In this study, researchers conducted data analysis through data reduction, data presentation, and verification (drawing conclusions). The results showed that (1) the process of forming social attitudes of seventh-grade students of SMP Brawijaya Smart School Malang through social studies learning methods was carried out by the teacher by involving two factors, namely internal factors (students) and external factors (school, home, and community environment. ), (2) the forms of student social attitudes can be seen by the existence of activities 
in class and outside the classroom (extracurricular activities) as well as school culture and regulations, and school culture (3) as a whole from some of the social attitudes of students who experience the most visible changes, namely changes in manners and discipline

Keywords: Social Attitudes; Social Studies Learning Method

\section{PENDAHULUAN}

Fenomena perubahan sosial karena arus globalisasi serta perkembangan teknologi yang sangat pesat memiliki dampak positif maupun negatif bagi generasi penerus di Indonesia (Sari \& Resmi, 2020). Sisi positif adalah mempercepat proses ilmu pengetahuan dan menumbuhkan karakter yang baik. Namun apabila dalam membina tidak memiliki suatu sistem yang baik akan menuju ke arah yang negatif. Salah satu contoh negatif misal adalah kasus bullying. Berdasarkan hasil survai dari Komisi Perlindungan Anak Indonesia menerima pengaduan kasus kekerasan fisik dan psikis terhadap anak di pendidikan. Sebanyak 153 kasus kekerasan terjadi di 2019 yang terdiri dari anak korban kebijakan, anak korban kekerasan fisik dan bullying (jppn.com, 2019). Perisiwa kasus bullying tersebut menunjukkan mulai melunturnya sikap sosial dimana diantaranya perundungan, intoleransi dan, kekerasan seksual di lingkungan pendidikan. Sikap ini menunjukkan cerminan dari rasa keperdulian dan empati terhadap sesama. Dibutuhkan suatu sistem Pendidikan yang mampu menjadi solusi untuk mengajarkan sikap sosial kepada generasi bangsa Indonesia.

Proses pendidikan di Indonesia sudah cukup baik, namun pemerintah terus berupaya dalam mengembangkan kebijakan Pendidikan yang sesuai dengan perubahan zaman. Maka dibutuhkan Pendidikan yang tidak hanya terfokus pada pembentukan faktor intelektual saja, tetapi juga pembentukan faktor lain yang harus dimiliki tiap individu seseorang, yang dimaksud disini adalah faktor prilaku. Jadi, tujuan pendidikan disini bukan hanya untuk mendidik peserta didik menjadi individu yang berpengetahuan, tetapi juga membangun kepribadiannya agar mempunyai sikap yang mulia (Fatchul, 2011). Wujud dari semua adalah terbentuknya karakter pada setiap generasi penerus bangsa Indonesia. Hal ini apa yang telah ditetapkan oleh pemerintah terkait penguatan Karakter merupakan salah satu misi pembangunan nasional sebagaimana tercantum pada UU RI. No. 17 Tahun 2007 mengandung karakter (Marhayani, 2018). Kemudian diperkuat dalam Permendikbud no. 20 tahun 2018 tentang penguatan pendidikan karakter.

Pembentukan karakter erat dengan pembentukan sikap sosial dari siswa. Hal ini meniti beratkan kepada dalam proses kehidupannya, manusia mempunyai dua peranan yakni sebagai makhluk individu dan makhluk sosial pasti akan menampakkan tingkah lakunya dalam kehidupan sosial. Hasil tingkah laku tersebut muncul dan akan menyebabkan suatu peristiwa yang saling mempengaruhi antar sesama, sehingga melahirkan berbagai macam sikap sosial tersebut yang nantinya akan menghiasi pola interaksi tingkah laku setiap individu dalam masyarakat (Nursid, 1984). Hal ini lah yang kemudian membangun toleransi, empati dan keperdulian dalam setiap manusia sebagai mahluk sosial.

Pendidikan atau mendidik tidak hanya mentransfer ilmu saja, namun pendidikan juga dpat mengubah karakter dan watak sesorang agar menjadi lebih baik (Sari \& Resmi, 2020). Hal ini juga mengacu pada kurikulum 2013 penekanan Pendidikan lebih kepada peningkatan dan keseimbangan soft skills dan hard skills yang meliputi kompetensi sikap, keterampilan, dan pengetahuan. Kemudian, kedudukan kompetensi yang semula diturunkan dalam mata pelajaran berubah menjadi mata pelajaran dikembangkan dari kompetensi. Selain itu pembelajaran lebih bersifat termatik integrative dalam semua mata pelajaran. Dengan demikian dapat dipahami bahwa kurikulum 2013 adalah sebuah kurikulum yang dikembangkan untuk meningkatkan dan menyeimbangkan kemampuan soft skill dan hard skill yang berupa sikap, keterampilan dan 
pengetahuan (Tiara \& Sari, 2019).

Sikap sosial sangat dibutuhkan untuk menjalin hubungan dengan orang lain dalam kehidupan sehari-hari, guna untuk menciptakan suasana hidup yang damai, rukun, nyaman, dan tentram dimana pun kita berada. Khsusunya siswa dalam lembaga pendidikan. Proses pembentukan karakter sikap sosial antara lain melalui pembelajaran IPS. Hal ini dikarena pembelajaran IPS memiliki kompetensi, yakni kompetensi personal, kompetensi sosial dan kompetensi intelektual. Sesuai dengan tuntutan zaman dan perkembangan kehidupan masyarakat, pembelajaran IPS harus menggunakan pendekatan interdispliner/pembelajaran terpadu (Marhayani, 2018).

Menurut Nasution (dalam Utami et al., 2019) mengemukakan IPS merupakan program pendidikan yang secara pokok mempersoalkan manusia dengan lingkungan alam fisik maupun lingkungan sosialnya. Bahan pembelajaran IPS diambil dari berbagai ilmu sosial seperti Geografi, Sejarah, Ekonomi, Anthropologi, Sosiologi, Politik, dan Psikologi.Sejatinya IPS merupakan mata pelajaran yang sangat penting dan kompleks dalam mempelajari fenomenafenomena sosial yang terjadi dalam masyarakat. Pada proses pembentukan sikap sosial disekolah, dapat melalui pembelajaran IPS. Hal ini sesuai dengan beberapa hasil penelitian (Marhayani, 2018; Natalia, 2013; Ratnasari, 2017; Sari \& Resmi, 2020; Suyanti, 2017) terkait pembentukan sikap sosial melalui pembelajaran IPS. Hasil menununjukkan pada proses pembelajaran IPS selain bertugas menyampaikan materi, juga untuk membentuk sikap sosial siswa.

Fakta unik digambarkan pada proses pembentukan sikap sosial pada SMP Brawijaya Smart School Malanng. Hasil wawancara dengan guru IPS serta bagian kesiswaan di SMP Brawijaya Smart School Malang siswa memiliki tingkat sikap sosial yang baik. Keunikan karakteristik siswa dan merupakan sekolah yang memiliki berbagai keunggulan namun tetap mengedepankan pada pembentukan karakter pada siswa. Kolaborasi sekolah lingkungan keluarga dan masyarakat menjadi slogan dalam pengembangan sikap sosial siswa. Sehingga sikap sosial yang muncul dalam diri siswa dipengaruhi oleh lingkungan sosialnya yakni berupa lingkungan keluarga, sekolah, dan, masyarakat terpolakan. Salah satu jalannya yakni dengan mengemas materi pembelajaran IPS melalui metode pembelajaran yang dapat membentuk sikap sosial didalamnya dengan mengaitkan kepada kehidupan siswa sehari-hari. Dengan begitu materi dapat tersampaikan dengan baik serta dalam diri siswa akan terbentuk pula sikap sosial siswa karena contoh langsung disekitar mereka. Sikap sosial yang dikembangkan disekolah mencakup perilaku jujur, disiplin, tanggung jawab, peduli, santun, serta percaya diri.

\section{METODE}

Pada penelitian ini, menggunakan pendekatan kualitatif deskriptif. Pendekatan ini digunakan untuk (1) menggambarkan proses pembentukan sikap sosial siswa melalui metode pembelajaran IPS (2) mendeskripsikan bentuk-bentuk sikap sosial siswa yang dibentuk melalui metode-metode pembelajaran IPS kelas VII SMP Brawijaya Smart School Malang, (3) mendeskripsikan perubahan sikap sosial siswa setelah terjadi proses pembentukan sikap sosial melalui metode-metode pembelajaran IPS kelas VII SMP Brawijaya Smart School Malang. Penelitian yang bersifat kualitatif lebih menekankan pada proses bukan pada hasil. Bogdan dan Taylor mengatakan bahwa, metode kualitatif yaitu sebagai prosedur penelitian yang menghasilkan data deskriptif berupa kata-kata tertulis atau lisan dari orang-orang atau perilaku yang diamati (Moleong Lexy J., 2002). Pada pengambilan data dengan terjun secara langsung sebagai subyek penelitian. Penelitian dilaksanakan SMP Brawijaya Smart School Malang. Alasan memilih lokasi ini sudah mengetahui sedikit banyak keadaan sekolah tersebut, serta sekolah tersebut merupakan Sekolah Menengah Pertama (SMP) terbaik dan pilihan di daerah 
Kota Malang. Subyek penelitian pada kelas VII, dan guru IPS, Kepala Sekolah, waka kurikulum, serta waka kesiswaan sebagai daya pendukung dan penguat data. Teknik pengumpulan data yakni dengan cara wawancara, observasi, dan dokumentasi. Teknik analisis data yang digunakan adalah melalui reduksi data, penyajian data dan verifikasi (penarikan kesimpulan).

\section{HASIL DAN PEMBAHASAN Hasil}

\section{Proses Pembentukan Sikap Sosial Siswa Melalui Metode Pembelajaran IPS Kelas VII C Di SMP Brawijaya Smart School Malang}

Mengacu pada kurikulum 2013, bahwa terdapat beberapa aspek didalamnya yakni (aspek pengetahuan, aspek sikap sosial, aspek relegius, serta aspek keterampilan) yang perlu dikembangkan dalam proses pembelajaran pada setiap mata pelajaran, salah satunya yakni mata pelajaran IPS. Dengan melalui metode Pembelajaran IPS kelas VII di SMP Brawijaya Smart School Malang merupakan salah satu langkah dalam pembentukan sikap sosial.

Proses pembentukan sikap sosial disini sangat penting dalam rangka membentuk sikap sosial siswa agar menjadi pribadi yang lebih baik. Proses pembentukan sikap dipengaruhi oleh dua faktor yakni faktor internal (fisiologis dan psikologis) dan faktor eksternal (pengalaman, situasi, norma-norma, hambatan, serta pendorong).

Mayoritas Siswa-siswi SMP Brawijaya Smart School Malang khususnya pada Kelas VII merupakan golongan keluarga menengah ke atas, dengan status ekonomi yang bisa dibilang mampu. Pekerjaan orang tua mereka rata-rata menjadi pegawai kantoran, dimana harus dituntut untuk bekerja mulai dari jam 08.00 sampai dengan jam 16.00. hal tersebut menjadikan mereka para orang tua mempunyai sedikit waktu untuk bertatap muka dengan anaknya, sampai-sampai mereka jarang memberi perhatian maupun mengontrol bagaimana perkembangan sekolah anaknya mulai dari belajar mereka sampai dengan bagaimana kebiasaan mereka dalam bersikap. Hal tersebut sejalan dengan apa yang telah dipaparkan oleh salah satu siswi kelas VII yang bernama Naya yang menggambarkan proses pembentukan sikap sosial diajarkan oleh guru dan juga di contohkan sehingga siswa menangkap keteladanan yang diberikan oleh guru IPS.

Tentunya pembentukan sikap sosial dalam diri siswa kelas VII SMP Brawijaya Smart School tidak terlepas dari peran orang tua sebagai sumber pendidikan utama diluar sekolah. Melalui proses interaksi sosial yang secara terus menerus berlangsung dalam keluarga tentunya akan membawa pengaruh baik sedikit maupun banyak dalam diri anak.

Mengarah pada pembentukan sikap sosial siswa kelas VII SMP Brawijaya Smart School Malang. Melalui metode pembelajaran IPS salah satunya sebagai jalan untuk membentuk sikap sosial dalam diri siswa. Metode pembelajaran sangat berguna dalam menunjang proses pembentukan sikap sosial siswa. Selain melalui metode pembelajaran sebagai jalan untuk membentuk sikap sosial siswa, guru IPS kelas VII SMP Brawijaya Smart School mempunyai cara lain juga dalam membentuk sikap sosial siswa salah satunya yakni melalui nasehat serta teguran kepada siswa yang berbuat melanggar saat proses pembelajaran di kelas. Hal ini sesuai dengan pernyataan Ibu Yuli Puji Astuti selaku Guru IPS, memberikan nasihat kepada siswa terkait nilai-nilai yang harus di miliki sebagai mahluk sosial serta memberikan contoh langsung kepada siswa.

Tugas guru disekolah bukan hanya sebatas penyampai ilmu pengetahuan saja, melainkan lebih dari itu. Salah satu tugasnya yakni membentuk sikap dalam diri peserta didik, utamanya sikap sosial. Terlebih lagi dalam mata pelajaran IPS. Melalui metode pembelajaran IPS diharapkan dapat membentuk sikap sosial yang baik. Di lingkungan sekolah guru sebagai tokoh sentral yang setiap saat menjadi perhatian peserta didik, maka dari itu segala bentuk kepribadian (kompetensi personal) guru akan menjadi sebuah keteladanan yang nantinya akan ditiru oleh 
peserta didik.

Selain melalui metode pembelajaran IPS, pembentukan sikap sosial siswa juga didukung oleh kegiatan sekolah (ekstrakulikuler) meliputi bakti sosial, bela negara, pramuka, dan lain sebagainya. Dimana kegiatan ekstrakulikuler tersebut dapat dilakukan melalui jalan metode karya wisata.

Tidak hanya kegiatan ekstrakulier saja yang dapat mendukung terbentuknya sikap sosial siswa melalui metode pembelajaran IPS, dengan adanya peraturan sekolah serta budaya sekolah juga turut ikut serta mendukung dalam pelaksanaanya.

\section{Bentuk-Bentuk Sikap Sosial siswa yang dibentuk Melalui Metode Pembelajaran IPS Kelas VII di SMP Brawijaya Smart School Malang}

Bentuk-bentuk sikap sosial sudah sangat jelas termuat dalam kurikulum 2013 yang wajib ada dalam semua mata pelajaran khususnya mata pelajaran IPS sendiri, yang notabennya materinya sendiri pun membahas mengenai masalah sosial baik di lingkungan masyarakat maupun lingkungan sekolah. Berikut hasil observasi dan wawancara mengenai beberapa bentuk sikap sosial yang dapat dibentuk melalui metode pembelajaran IPS:

a. Sikap jujur

Berkaitan dengan sikap jujur pada siswa kelas VII SMP Brawijaya Smart School, menurut Ibu Yuli Puji Astuti Selaku Guru IPS. Dari hasil wawancara tersebut, dapat terlihat sikap jujur saat siswa kelas VII mengerjakan tugas IPS, soal UTS dan UAS, mayoritas mereka mengerjakan secara mandiri tanpa mencontek teman sebelahnya, hanya ada satu dua anak saja yang belum bisa mengerjakan tugas secara mandiri.

b. Sikap disiplin

Pada kegiatan pembelajaran IPS sendiri, pembentukan sikap disiplin dapat terlihat pada saat proses pemberian tugas sampai dengan pengumpulan tugas. Ibu Yuli selaku guru IPS mengaku masih tetap berusaha sebaik mungkin agar siswa tetap taat dengan segala peraturan yang ada. Hal ini tampak jelas dikatakan Ibu Yuli Puji Astuti saat peneliti melakukan wawancara.

Selain dapat dibentuk dengan proses pemberian tugas pada siswa, sikap disiplin juga dapat dibentuk melalui kegiatan maupun peraturan yang ada di sekolah. Seperti halnya masalah ketepatan siswa saat datang ke sekolah serta datang ke kelas. Rata-rata siswa-siswi SMP Brawijaya Smart School Malang mereka mengaku datang ke sekolah sebelum jam masuk sekolah (06.45) dikarenakan mereka takut kena pengurangan point dan terlambat pada kegiatan Morning Greeting oleh wali kelas.

c. Sikap santun

Dari hasil observasi peneliti tampak mengamati saat kegiatan pembelajaran di kelas VII mata pelajaran IPS terdapat satu dua anak yang masih berbicara sendiri saat guru menjelaskan materi. Ibu Yuli Puji Astuti selaku guru IPS saat itu langsung menegur siswa tersebut dan menasehatinya secara perlahan kemudian siswa tersebut diam dan tidak membantah guru (Observasi, 10 Maret 2020).

Peneliti juga mewawancarai siswa terkait sikap menghormati kepada orang lain yaitu mendengarkan guru dan teman saat sedang berbicara atau sedang menjelaskan materi di depan kelas, dengan alasan agar mereka mengerti, dan dapat mengerjakan soal ketika ujian. Saat itu peneliti sedang melakukan wawancara dengan salah satu siswa kelas VII yang bernama Gathan. d. Sikap peduli

Sikap peduli itu terlihat saat guru IPS memberi tugas kepada siswa, dalam proses mengerjakan kadang-kadang ada beberapa siswa yang belum faham mengenai maksud soal yang tertera. Dengan muncul masalah tersebut terlihat ada siswa yang meminta bantuan kepada 
temannya untuk menjelaskan maksud soal tersebut, dengan senang hati mereka yang dimintai bantuan langsung tergerak untuk membaantunya. Hal ini dipertegas dengan hasil wawancara peneliti dengan Ibu Yuli Puji Astuti, S. Pd.

e. Sikap percaya diri

Sikap percaya diri juga merupakan salah satu sikap yang dibentuk di kelas VII C melalui pembelajaran IPS khususnya. Seperti penuturan Ibu Yuli Puji Astuti, S. Pd. pada hasil wawancara Dapat disimpulkan bahwa rata-rata sikap percaya diri siswa kelas VII C bisa dibilang baik. Hal ini dapat kita lihat dari penjelasan yang disampaikan oleh guru IPS sendiri, temuan peneliti, serta hasil wawancara peneliti dengan siswa.

f. Sikap tanggung jawab

Dari hasil penelitian ditemukan bahwa seluruh siswa kelas VII C dapat menyelesaikan tugas sekolah ataupun tugas rumah dengan baik, secara individu maupun kelompok. Dikarenakan di SMP Brawijaya Smart School sendiri mempunyai program yang namanya penjajakan. Dengan program itu siswa-siswi merasa ketakukan untuk menyelesaikan dan mengumpulkan semua tugas dengan tuntas. Hal ini dipertegas dengan penjelasan yang disampaikan Ibu Yuli Puji Astuti saat melakukan wawancara dengan peneliti, beliau mengatakan bahwa :

Berdasarkan data yang diperoleh peneliti melalui observasi Pembentukan sikap disiplin juga terjadi dengan adanya program piket kebersihan kelas. Peneliti melihat tertempel jadwal piket kelas di mading bagian depan kelas. Piket kelas biasanya dilaksanakan siswa saat selesai pembelajaran jam terakhir. Dalam pelaksanaan piket kelas rata-rata siswa-siswi hanya sebatas membalikkan bangku mereka. tidak sampai menyapu lantai (Observasi, 10 Maret 2020). Temuan peneliti di lapangan saat jam istirahat berlangsung, kondisi kelas VII terlihat tampak bersih, hal ini dikarenakan siswa-siswinya taat membuang sampah pada bak sampah masing-masing yang sudah tersedia di depan kelas mereka (Observasi, 10 Maret 2020).

g. Sikap toleransi

Sikap menghargai antar sesama ini juga dapat dibentuk, baik dalam proses pembelajaran maupun di luar pembelajaran. Sikap toleransi dapat dibentuk yakni salah satunya siswa tidak memilih-milih teman yang miskin atau yang kaya, maupun teman yang pintar atau tidak pintar dalam hal berteman di sekolah maupun di rumah. Mereka diajarkan untuk tidak melihat ras-ras atau golongan tertentu. Selanjutnya Ibu Yuli Puji Astuti, S. Pd. Selaku Guru IPS.

Dari hasil observasi tampak mayoritas latar belakang siswa SMP Brawiijaya Smart School khususnya kelas VII yakni beragama Islam, akan tetapi ada beberapa siswa yang beragama Hindhu, Budha, dan Konghucu. Dengan keberagamaan agama mereka bersatu bukan malah bercerai berai. Hal ini dikarenakan sikap toleransi mereka yang sangat kuat (Observasi, 10 Maret 2020). Dapat disimpulkan dari beberapa hasil wawancara dan observasi peneliti, bahwa SMP Brawijaya Smart School mampu membentuk sikap toleransi siswa dengan baik.

h. Sikap Kerjasama

Sikap kerjasama merupakan salah satu sikap sosial yang dibentuk di kelas VII khususnya. Dari hasil observasi peneliti menemukan tepatnya saat dalam proses pembelajaran IPS sendiri rata-rata anak mampu menjalin kerjasama antar temannya seperti dalam hal mengerjakan tugas atau proyek. Namun hanya ada satu siswa dalam satu kelas yang sulit untuk diajak kerjasama (Observasi, 10 Maret 2020). Hal ini juga dibuktikan dengan hasil wawancara peneliti dengan Ibu Yuli Puji Astuti, S. Pd. selaku guru IPS. Ibu Yuli Puji Astuti selaku guru IPS juga selalu berusaha untuk mencari jalan keluar agar anak-anak yang tidak mampu bekerjasama, dilatih untuk bisa kerjasama melalui pemberian tugas yang diberikan kepada siswa-siswi.

Selain melalui kegiatan diatas, sikap kerjasama juga dapat di bentuk melalui kegiatan ekstrakulikuler di sekolah seperti halnya pramuka. Pada kegiatan pramuka terdapat agenda 
tahunan yakni perkemahan. Dalam kegiatan perkemahan ini siswa dibentuk menjadi beberapa kelompok atau regu dengan tujuan agar mereka saling borkompetisi antar regu. SMP Brawijaya Smart School membuat beberapa macam kegiatan lomba diantaranya, scouting challenge, scouting skills, KIM, food festival, api unggun, jelajah dan refleksi. Dimana dalam berbagai macam perlombaan tersebut siswa dilatih untuk saling kerjasama antar anggota kelompok. (Dokumentasi, 18 Februari 2020).

\section{Perubahan Sikap Sosial Siswa Setelah Terjadi Proses Pembentukan Sikap Sosial Melalui Metode Pembelajaran IPS Kelas VII di SMP Brawijaya Smart School Malang}

Dengan adanya proses pembentukan sikap sosial melalui metode pembelajaran IPS Terpadu serta dibantu dengan daya pendukung yakni berupa peraturan sekolah, budaya sekolah serta program-program yang terangkum dalam kegiatan-kegiatan ekstrakulikuler yang ada di sekolah meliputi pramuka, bela negara, keputrian, bakti sosial, dan lain sebagainya. Dimana kegiatan-kegiatan tersebut dapat dilakukan melalui metode pembelajaran yakni metode karya wisata, sepertihalnya metode pembelajaran pada umumnya. Yang mana melalui cara-cara tersebut akan membawa pengaruh dalam proses pembentukan sikap dalam diri siswa. Wujud akhir dalam pelaksanaan proses pembentukan sikap sosial ini diharapkan adanya sebuah perubahan sikap sosial dalam diri siswa untuk menjadi lebih baik dari sebelumnya.

Bapak Muhammad Arif, S.Si, M. Pd. selaku Kepala Sekolah SMP Brawijaya Smart School juga mengakui adanya perubahan sikap sosial dalam diri siswa, beliau menyatakan bahwa perubahan banyak terjadi pada sikap disiplin siswa. Hal ini dipertegas dengan pernyataan Bapak Muhammad Arif, S.Si, M. Pd. saat melakukan wawancara dengan peneliti. Dari hasil wawancara dari semua pihak sekolah yakni (guru IPS, Waka Kurikulum, Waka Kesiswaan, serta Kepala Sekolah) dapat disimpulkan bahwa terjadi perubahan sikap sosial (jujur, sopan santun, percaya diri, kerjasama, serta toleransi) pada siswa kelas VII, akan tetapi yang paling banyak mengalami perubahan yakni terletak pada sikap sopan santunnya yang diterapkan dengan budaya 3S (senyum, salam, sapa) saat di sekolah.

Pihak keluarga sendiri mengakui perubahan sikap sosial yang ada pada diri anaknya, utamanya pada sikap disiplin, hal ini terlihat saat mereka mengerjakan PR (pekerjaan rumah) dari sekolah mereka tidak pernah telat untuk mengerjakan, selain itu juga terlihat saat mereka berangkat sekolah, mereka berusaha berangkat lebih awal sebelum masuk jam sekolah dikarenakan mereka takut terkena pengurangan point (nyawa). Hal ini didukung dengan hasil wawancara peneliti dengan Ibu Yuli Puji Astuti selaku guru IPS yang turut menyampaikan hal yang dirasakan oleh para wali murid. Dari hasil wawancara diatas, selain pihak keluarga yang ikut merasakan perubahan tersebut pihak masyarakat sekitar juga ikut merasakan perubahan tersebut. Salah satunya dengan keikutsertaan para siswa-siswi di masyarakat dalam mengikuti atau menjadi anggota karang taruna.

\section{Pembahasan \\ Proses Pembentukan Sikap Sosial Siswa Melalui Metode Pembelajaran IPS Kelas VII Di SMP Brawijaya Smart School Malang}

Mengacu pada kurikulum 2013, bahwa terdapat beberapa aspek didalamnya yakni (aspek pengetahuan, aspek sikap sosial, aspek relegius, serta aspek keterampilan) yang perlu dikembangkan dalam proses pembelajaran pada setiap mata pelajaran, salah satunya yakni mata pelajaran IPS. Dengan melalui metode Pembelajaran IPS kelas VII di SMP Brawijaya Smart School Malang merupakan salah satu langkah dalam pembentukan sikap sosial.

Proses pembentukan sikap sosial disini sangat penting dalam rangka membentuk sikap sosial siswa agar menjadi pribadi yang lebih baik. Sikap itu tidak dibawa sejak lahir, akan tetapi sikap 
dapat dibentuk sepanjang perkembangan individu atau pribadi sendiri (Bimo, 2003). Proses pembentukan sikap dipengaruhi oleh dua faktor yakni faktor internal (fisiologis dan psikologis) dan faktor eksternal (pengalaman, situasi, norma-norma, hambatan, serta pendorong), (Bimo, 2003).

Pembentukan sikap sosial anak dapat terjadi melalui pengalaman yang berulang-ulang atau dapat pula melalui suatu pengalaman yang disertai perasaan yang mendalam. Melalui proses imitasi atau proses peniruan yang terjadi tanpa disengaja maupun sengaja, kadangkala dari pengaruh orang yang dianggap penting atau berwibawa dalam pandangannya, dengan cara meniru orang lain yang didasari keterikatan emosional dalam hal ini lebih banyak dalam arti berusaha menyamai seperti pada orang tua maupun pada guru di sekolah.

Reaksi individu yang diberikan terhadap objek sikap dapat bersifat positif dan juga dapat bersifat negatif. Reaksi tersebut salah satunya dipengaruhi oleh proses belajar mereka yakni saat individu berada di lingkungan sekolah maupun di luar sekolah (Bimo, 2003).

Banyak orang berpendapat bahwa mengajarkan serta membentuk sikap dalam diri anak adalah tanggung jawab orang tua dan guru dalam lembaga pendidikan maupun keagamaan. Guru merupakan orang yang paling berpengaruh dalam pembentukan sikap sosial pada anak sewaktu anak berada di lingkungan sekolah. Guru berkedudukan sebagai pengganti orang tua siswa saat berada di sekolah. Guru dituntut bukan hanya mentransferkan ilmu pengetahuan saja kepada peserta didik, tetapi juga dituntut untuk melakukan tindakan dan cara hidup yang sesuai dengan apa yang diajarkan (Stephen, 2003).

Mary Go Setiawan menjelaskan beberapa peran psikologi pendidikan yang menyelidiki unsur kejiwaan peserta didik, salah satunya dalam membentuk kepribadian pendidik. Kepribadian pendidik memberikan pengaruh yang amat besar bagi sikap peserta didik (Syaiful, 2003).

Menjadi guru tidaklah sebuah hal yang sangat mudah, sebab seorang guru harus memiliki sikap yang baik yang nantinya akan ditiru oleh anak didik mereka. Seperti yang termuat dalam terjemah hadits ini "Setiap kamu bertanggung jawab atas kepemimpinannya: maka seorang imam adalah dan dia bertanggung jawab atas kepemimpinannya, seorang laki-laki adalah pemimpin di dalam keluarganya dan dia bertanggung jawab atas kepemimpinannya, perempuan adalah pemimpin rumah suaminya dan diaa bertanggung jawab atas kepemimpinannya, pembantu adalah pemimpin/penangggung jawab terhadap harta tuannya dan dia bertanggung jawab atas kepemimpinannnya, seorang anak adalah pemimpin terhadap harta ayahnya dan dia bertanggung jawab atas kepemimpinannya, maka setiap kamu adalah pemimpin dan setiap kamu bertanggung jawab atas kepemimpinannya"

Dalam Islam sendiri telah dijelaskan bahwa seorang guru adalah pemimpin dan sekaligus pelayan bagi peserta didiknya yang memiliki kewajiban untuk memimpin dan melayani peserta didiknya dengan sebaik-baiknya, karena pada saatnya akan diminta pertanggung jawaban atas kepemimpinannya tersebut. Guru sebagai orang tua kedua dan sekaligus penanggung jawab pendidikan anak didiknya harus bertanggung jawab atas sikap, tingkah laku, dan perbuatan anak didiknya.

Dari hasil observasi serta wawancara peneliti guru dapat menjadi suri tauladan yang baik bagi siswa-siswi di SMP Brawijaya Smart School Malang. Terutama dalam proses pembelajaran IPS, selain guru dapat mengajarkan bagaimana cara bersikap sosial dengan baik melalui contoh maupun nasehat yang telah diberikan, akan tetapi yang terpenting yakni sebuah contoh yang berbentuk perbuatan atau aksi yang nyata, yang nantinya akan dilihat secara langsung oleh siswa sehingga siswa dengan secara sengaja akan meniru perbuatan yang telah dilakukan.

Berdasarkan hasil wawancara, observasi, serta dokumentasi di lapangan. Dapat diketahui bahwa proses pembentukan sikap sosial melalui metode pembelajaran IPS kelas VII di SMP 
Brawijaya Smart School Malang sudah di terapkan oleh guru pengampuh mata pelajaran IPS sendiri. Akan tetapi dilapangan peneliti juga menemukan proses pembentukan sikap sosial di luar kelas dalam arti di sekolah, yang ikut serta mendukung proses pembentukan sikap sosial dalam mata pelajaran IPS.

Dalam proses pembelajaran IPS guru dapat membentuk sikap siswa melalui metode pembelajaran seperti metode diskusi, kerja proyek, serta melalui tauladan dari guru sendiri dan berupa nasehat nasehat yang di sampaikan di sela-sela proses pembelajaran berlangsung. Sedangkan proses pembentukan sikap sosial di luar kelas yakni terbentuk melalui program sekolah yang berupa kegiatan ekstrakulikuler seperti bela negara, bakti sosial, pramuka, dan lain sebagainya, serta melalui peraturan-peraturan yang diterapkan oleh pihak sekolah. Dimana kegiatan ekstrakulikuler tersebut dapat dikemas dengan metode karya wisata.

Dalam proses pembentukan sikap sosial selain lingkungan sekolah yang menjadi daya pengaruh, lingkungan keluarga juga mempunyai pengaruh yang sangat besar juga, siswa siswi kelas VII SMP Brawijaya Smart School Malang merupakan kumpulan siswa-siswi dari latar belakang keluarga menengah keatas, dimana orang tua mereka kebanyakan menjadi pegawai kantor yang sangat disibukkan dengan urusan dunia kerja mereka. Sehingga jarang memperhatikan maupun mengontrol perkembangan sikap anak mereka. Hal ini diakui oleh siswa-siswi kelas VII SMP Brawijaya Smart School Malang, mereka mengakui sendiri bahwa saat berada dirumah mereka merasa sangat kurang perhatian terhadap tugas sekolah, akan tetapi ada juga orang tua yang perhatian dalam mengontrol sikap anak mereka. Hal ini sesuai dengan pengakuan oleh salah satu siswi Kleas VII.

Dapat disimpulkan oleh peneliti dari hasil wawancara peneliti dengan beberapa siswasiswi kelas VII SMP Brawijaya Smart School Malang bahwa rata-rata orang tua mereka bekerja sebagai pegawai kantor sehingga tidak banyak waktu untuk mereka saling berkomunikasi dan bertatap muka. Guru mata pelajaran IPS Ibu Yuli Puji Astuti, S. Pd. Mengaku bahwa intensitas waktu siswa antara di rumah dan di sekolah lebih banyak di sekolah dikarenakan SMP Brawijaya Smart School juga sudah menerapkan sistem Full Day School yang kegiatan akademisnya dimulai pukul 06.45 dan berakhir pukul 15.30 atau sehabis sholat Ashar, sehingga pengaruh lingkungan sekolah cenderung lebih besar dari pada lingkungan rumah. Akan tetapi lebih baiknya antara pihak orang tua dan pihak sekolah saling mengisi dan bukan meniadakan dalam membentuk sikap anak. Untuk itu lah komunikasi orang tua dan anak, dan komunikasi orang tua dengan pihak sekolah menjadi salah satu hal yang sangat penting untuk dilakukan.

Dalam menghadapi hal tersebut pihak Kepala Sekolah SMP Brawijaya Smart School mengatakan dalam wawancaranya dengan peneliti bahwa beliau menjadikan hal tersebut sebagai solusi dalam keefektifan proses pembentukan sikap sosial pada peserta didik dengan cara membuat program pertemuan wali siswa dengan wali kelas yang wajib minimal dilakukan dalam 2 kali pertemuan dalam satu tahun diluar pembagian rapot hasil belajar, dimana dalam pertemuan tersebut terdapat beberapa hal yang disampaikan terkait dengan perkembangan peserta didik di sekolah, yakni penyampaian grafik hasil belajar peserta didik, penyampain besar point pelanggaran peserta didik (yang merupakan nyawa peserta didik selama satu tahun di sekolah), serta acara parenting pada wali siswa. Dengan program itulah kepala sekolah mengaku proses pembentukan sikap sosial di SMP Brawijaya Smart School dapat dilakukan secara maksimal.

Selain program tersebut yang sudah diterapkan sejak lama, kepala sekolah juga mempunyai inisiatif menerapkan program baru yakni dengan memberikan reward atau penghargaan kepada siswa yang poinnya masih stabil yakni 100 point sebagaimana point (nyawa) mereka saat di awal tahun ajaran baru. Program ini sangatlah berhubungan dan mendukung dalam pembentukan sikap sosial sebagaimana telah dijelaskan dalam teori sikap sosial yakni Instrumental Conditioning (teori belajar) bahwa seseroang berperilaku tertentu untuk 
mendapatkan sesuatu. Penerapan prinsip pada teori ini yakni prinsip pemberian hadiah dan hukuman terhadap munculnya respon-respon dari subyek. Respon yang muncul sesuai dengan yang dikehendaki diberi hadiah, sedangkan respon yang muncul tidak sesuai dengan kehendak maka dikenai hukuman.

\section{Bentuk-Bentuk Sikap Sosial siswa yang dibentuk Melalui Metode Pembelajaran IPS Kelas VII C di SMP Brawijaya Smart School Malang}

Berikut ini beberapa pembahasan mengenai bentuk-bentuk sikap sosial yang terbentuk melalui metode pembelajaran IPS kelas VII SMP Brawijaya Smart School Malang. Dalam pembentukan sikap sosial tersebut di dukung dengan beberapa kegiatan sekolah (kegiatan ekstrakulikuler) yang meliputi bela negara, pramuka, bakti sosial, dan lain sebagainya, dimana kegiatan-kegiatan tersebut dapat dilakukan melalui metode karya wisata. Selain melalui metode pembelajaran pembentukan sikap sosial juga dapat terbentuk dengan adanya budaya sekolah (3S-senyum, salam, sapa), serta peraturan-peraturan yang ada di sekolah. Bentuk-bentuk sikap sosial yang dimaksud disini yaitu :

a. Sikap jujur

Sikap jujur merupakan perilaku yang didasarkan upaya menjadikan sebagai orang yang selalu dapat dipercaya dalam perkataan, tindakan, dan pekerjaan (Ida Ayu Dewi Virani et al., 2016). Dalam islam telah dijelaskan mengenai perintah untuk berbuat jujur, dan hendaknya kita berteman maupun bergaul dengan orang yang berbuat jujur agar kita ikut untuk berbuat jujur, sebagaimana dalam al-qur'an surat At-Taubah ayat 119, yang artinya "Hai orang-orang yang beriman, bertakwalah kepada Allah dan hendaklah kamu bersama orang-orang yang benar" (Ash-Shobur, 2008).

Dari terjemahan ayat diatas dapat disimpulkan bahwa pentingnya kita manusia untuk selalu bersikap jujur. Untuk itu tidak ada salahnya seorang guru dan orang tua senantiasa membentuk sikap kejujuran dalam diri anaknya. Agar dalam diri anak tersebut terbentuk sikap jujur.

Salah satu bentuk nyata dari terbentuknya sikap jujur kelas VII SMP Brawijaya Smart School Malang, yakni saat siswa kelas VII mengerjakan tugas IPS, soal UTS dan UAS, mayoritas mereka mengerjakan secara mandiri tanpa mencontek teman sebelahnya, hanya satu dua anak saja yang belum bisa mandiri dalam mengerjakan tugas.

b. Sikap disiplin

Disiplin adalah tindakan yang menunjukkan perilaku tertib dan patuh pada berbagai ketentuan dan peraturan (Ida Ayu Dewi Virani et al., 2016). Dalam hal sikap disiplin ini juga telah dijelaskan oleh Ahmad Musthafa Al-Maraghi dalam tafsir Al-Maraghi menjelaskan bahwa untuk memahami hakikat dari kedisiplinan, antara lain yang telah dideskripsikan Allah dalam alqur'an surat Al-Ashr ayat 1-3. disiplin adalah keimanan yang kuat yang dapat menimbulkan dorongan untuk adanya niat memanfaatkan waktu (Dokumentasi, 7 Juni 2020).

Dari penjelasan diatas mengenai integrasi keislaman terhadap sikap disiplin, dapat disimpulkan diantara ajaran islam yang mulia yakni salah satunya sikap disiplin. Tidak menutup kemungkinan orang yang tingkat ilmunya tinggi akan tetapi tidak terbentuk sikap disiplin dalam dirinya maka orang itu tidak akan mencapai sebuah kesuksesan.

Salah satu bentuk nyata dari terbentuknya sikap disiplin kelas VII SMP Brawijaya Smart School Malang, yakni dalam kegiatan pemberian tugas sampai dengan pengumpulan tugas. Pada kegiatan tersebut guru IPS memberikan peraturan mengenai keterlambatan dalam pengumpulan tugas. Jika siswa melanggar akan dikenakan sanksi dengan tidak diberi nilai. Serta pada program sekolah yang biasa dinamakan penjajakan. Program tersebut dilaksanakan pada saat sebelum UTS dan UAS. Dalam program tersebut siswa harus wajib melunasi semua tanggungan tugas 
yang belum dikerjakan.

c. Sikap santun

Santun adalah perilaku hormat pada orang lain dengan bahasa yang baik (Ida Ayu Dewi Virani et al., 2016). Dalam Islam sendiri telah dijelaskan mengenai sikap santun yang termuat dalam sebuah ayat dalam surat An-Nur ayat 63 yang artinya "Janganlah kamu jadikan panggilan Rasul diantara kamu seperti panggilan sebagian yang lain" (Ash-Shobur, 2008). Dari ayat ini dapat disimpulkan bahwa ketika kita memanggil Nabi maka panggillah beliau dengan sopan santun dan penghormatan yang pantas untuk beliau, bukan seperti ketika sebagian kalian memanggil sebagian lainnya. Hal ini juga berlaku bagi siswa-siswi jika memanggil ataupun menyapa orang yang lebih tua baik itu orang tua maupun guru sebaiknya memanggil dengan panggilan yang baik dan sopan.

Salah satu bentuk nyata dari terbentuknya sikap santun kelas VII SMP Brawijaya Smart School Malang, yakni terlihat saat proses pembelajaran IPS berlangsung, jika terdapat siswasiswi yang membuat gaduh atau berbicara sendiri saat guru maupun temannya sedang menjelaskan materi, secara langsung guru IPS akan menegur siswa tersebut serta menasehati. Pada kelas VII sendiri hanya terdapat satu dua anak yang berbicara sendiri saat pembelajaran berlangsung. Temuan lain peneliti terkait bentuk sikap santun yaitu terlihat saat siswa sedang bertegur sapa dengan guru maupun temannya ketika di luar kelas, jika siswa bertegur sapa atau bertemu dengan guru yang sesama jenis mereka menyapanya dengan bersalaman.

d. Sikap peduli

Peduli adalah sikap atau tindakan yang selalu ingin memberi bantuan kepada orang lain atau masyarakat yang membutuhkan (Ida Ayu Dewi Virani et al., 2016). Dalam Islam telah dijelaskan mengenai sikap peduli tersebut, sebagaimana tertuang dalam surat Al-Maidah ayat 2, yang artinya "Dan tolong-menolonglah kamu dlam kebaikan dan ketakwaan. Dan janganlah tolong-menolonglah dalam berbuat dosa dan pelanggaran. Dan bertakwalah kepada Allah, sesungguhnya siksa Allah sangat berat" (Ash-Shobur, 2008). Dari ayat diatas sudah sangat jelas mengenai perintah untuk tolong menolong atau peduli terhadap sesama. Sejatinya kita manusia harus selalu bersyukur dan selalu memberi bantuan kepada orang lain. Kita manusia merupakan makhluk sosial yang tidak bisa hidup tanpa bantuan dari orang lain dimanapun kita berada dengan siapapun kita berinteraksi. Utamanya dilingkungan sekolah yang tentunya banyak tugas yang harus diselesaikan oleh siswa terkait dengan mata pelajaran maupun yang lain.

Salah satu bentuk nyata dari terbentuknya sikap peduli kelas VII SMP Brawijaya Smart School Malang, yakni sikap peduli dapat terbentuk dalam kegiatan pembelajaran IPS. Kala itu ada salah satu siswa yang belum paham mengenai soal maupun materi yang dijelaskan oleh guru IPS, mereka langsung bertanya atau meminta bantuan kepada teman sebelahnya untuk menjelaskan terkait hal yang ditanya. Dengan rasa senang dan ikhlas teman mereka yang dimintai bantuan langsung membantunya dengan tangan ringan. Selain itu juga terlihat saat mereka antar siswa sedang meminjam peralatan tulis. Mereka yang mempunyai peralatan tulis lebih dan sedang tidak digunakan secara langsung pasti mereka pinjamkan tanpa ada unsur paksaan.

e. Sikap percaya diri

Sikap percaya diri sangatlah penting untuk mengaktualisasikan potensi yang kita miliki. Dalam Islam telah dijelaskan mengenai sikap percaya diri, sebagaimana tertuang dalam surat Ali-Imran ayat 139 yang artinya "janganlah kamu bersikap lemah, dan janganlah (pula) kamu bersedih hati, padahal kamulah orang-orang yang paling tinggi (derajatnya), jika kamu orangorang beriman" (Ash-Shobur, 2008). Dari ayat diatas dapat disimpulkan bahwa kita manusia tidak boleh bersikap lemah dalam menghadapi apapun. kita harus yakin bahwa Allah akan selalu memberi pertolongan kepada hambanya dan kita juga harus percaya bahwa kita mempunyai 
derajat yang tinggi dihadapan Allah. Jika kita yakin akan hal itu maka kita termasuk orang yang beriman.

Salah satu bentuk nyata dari terbentuknya sikap percaya diri kelas VII SMP Brawijaya Smart School Malang, yakni pada kegiatan tanya jawab saat pembelajaran IPS. Siswa tampak sangat antusisas dalam menjawab pertanyaan. Meskipun pada kenyataannya saat guru IPS menjelaskan materi ada beberapa siswa yang menampakkan wajah tidak siap belajar dan saat mereka menjawab pertanyaan ke depan pun mereka menjawab dengan jawaban yang salah. Selain itu sikap percaya diri juga turut dibentuk dalam kegiatan belajar IPS dikelas. Para siswasiswi berani tampil di depan kelas saat mempresentasikan hasil karyanya baik secara individu maupun kelompok. Dikarenakan sebelum melakukan prsesntasi di depan mereka membagi pointpoint pekerjaan mereka masing-masing dan mempelajarinya dengan benar-benar.

f. Sikap tanggung jawab

Tanggung jawab adalah sikap peserta didik dalam melaksanakan tugas dan kewajibannya, yang harus dilakukan oleh individu sendiri, masyarakat, lingkungan, negara, dan Tuhan yang Maha Esa (Ida Ayu Dewi Virani et al., 2016).

Sikap tanggung jawab sangatlah diperlukan dalam diri kita masing-masing. Dengan bersikap tanggung jawab maka kita akan mudah di percaya oleh orang lain. Dalam Islam telah dijelaskan dalam sebuah hadits yang artinya "Tiap-tiap diri bertanggung jawab atas apa yang telah diperbuatnya."

Salah satu bentuk nyata dari terbentuknya sikap tanggung jawab kelas VII SMP Brawijaya Smart School Malang yakni, sikap tanggung jawab dapat terbentuk dengan adanya program sekolah yang bernama penjajakan. Dalam program tersebut siswa dilatih untuk bertanggung jawab atas tugas yang belum terselesaikan dikelas, sehingga saat itu pula tanggungan tugasnya harus diselesaikan. Selain itu dengan program piket kelas yang sudah tertempel di mading kelas diharapkan dapat membantu terbentuknya sikap tanggung jawab siswa. Akan tetapi dalam piket kelas tersebut rata-rata siswa hanya sebatas membalikkan bangku dan tidak sampai menyapu lantai.

g. Sikap toleransi

Toleransi adalah sikap menerima secara terbuka orang lain yang tingkat kematangan dan latar belakangnya berbeda (Muchlas \& Hariyanto, 2013). Sikap toleransi merupakan salah satu sikap dari sikap sosial yang wajib dimiliki. Dalam Islam pun telah dijelaskan mengenai sikap toleransi tersebut dalam surat Al-Baqarah ayat 256 yang artinya "Tidak ada paksaan untuk memasuki agama Islam. Sesungguhnya telah jelas jalan yang benar dari pada jalan yang sesat. Karena itu barangsiapa yang ingkar kepada Thaghut dan beriman kepada Allah, maka sesungguhnya ia telah berpegang kepada tali yang amat kuat (Islam) yang tidak akan putus. Dan Allah maha mendengar lagi maha mengetahui" (Ash-Shobur, 2008). Maksud dari ayat diatas adalah tidak dibenarkannya paksaan untuk memasuki agama Islam, akan tetapi ada kewajiban untuk selalu menyampaikan agama Allah kepada manusia dengan cara yang baik sehingga mereka masuk agama Islam dengan kesadaran dan kemauan sendiri.

Dari penjelasan ayat diatas dapat disimpulkan bahwa kita manusia tidak boleh memaksa orang lain untuk masuk ke dalam agama Islam, melainkan kita hanya memiliki kewajiban untuk menyampaikan ajaran-Nya dengan cara yang baik. Berkaitan dengan hal tersebut di SMP Brawijaya Smart School dimana siswanya berasal dari berbagai macam agama yakni Islam, Kristen, Konghucu, dan lain sebagainya. Untuk itu sikap toleransi harus dimiliki oleh para siswa dengan tujuan agar pembelajaran dapat dilakukan dengan baik tanpa ada kendala yang tidak diinginkan.

Salah satu bentuk nyata dari terbentuknya sikap toleransi kelas VII SMP Brawijaya Smart School Malang yakni, rata-rata siswa-siswi SMP Brawijaya Smart School Malang khususnya 
untuk kelas VII mereka tidak memilih-milih dalam berteman hal ini dibuktikan dengan saat mereka kelas VII naik ke kelas VIII meskipun temannya berbeda-beda saat di kelas VIII, mereka masih tetap berteman dekat dengan temannya saat di kelas VII dulu. SMP Brawijaya Smart School Malang membuat program keagamaan untuk para siswa-siswi sesuai dengan agama yang dianutnya.

h. Sikap kerjasama

Sikap kerjasama adalah bentuk proses sosial, dimana didalamnya terdapat akivitas teretntu yang ditunjukkan untuk mencapai tujuan bersama dan saling membantu dan memahami aktivitas masing-masing (Abdulsyani, 2007).

Sikap kerjasama sangatlah diperlukan dalam sebuah organisasi atau perkumpulan. Kerjasama sangatlah dianjurkan dalam hal kebaikan. Hal ini sangatlah jelas dalam Hadits rasul yang artinya "Permudalah dan jangan mempersulit, berilah kabar gembira dan jangan membuat orang lari, saling bekerjasamalah kalian berdua dan jangan bersedih" (HR. Al-Bukhari No.3038 dari Ahmadi \& Uhbiyati, 1991). Dari ayat diatas dapat disimpulkan bahwa kita manusia dianjurkan untuk selalu bekerjasama agar kita tidak merasa sedih akan beban yang kita miliki, apalagi bagi pelajar yang biasanya di sekolah banyak tugas maupun perlombaan yang harus diselesaikan secara berkelompok.

Salah satu bentuk nyata dari terbentuknya sikap kerjasama kelas VII SMP Brawijaya Smart School Malang yakni, mereka mengerjakan tugas atau proyek yang diberikan guru IPS secara berkelompok mereka mampu bekerjasama dengan baik, meskipun ada salah satu siswa yang cenderung di hindari oleh siswa-siswi lainnya. Hal ini terjadi bukan karena tidak suka atau memilih-milih, akan tetapi karena latar belakang anak tersebut yakni orang tuanya yang overprotektif terhadap anaknya dalam membatasi anaknya dalam berteman. Akan tetapi guru IPS sendiri mempunyai alternatif agar anak tersebut dilibatkan dalam kerja kelompok dengan cara melibatkan anak tersebut tahap atau bagian pada saat mengerjakan kerja kelompok, Sehingga kelompok tersebut bisa bekerjasama dengan maksimal. kerjasama siswa yang kedua yakni terbentuk dalam kegiatan ekstrakulikuler pramuka dalam agenda tahunan yakni perkemahan. Dalam kegiatan perkemahan tersebut siswa dibagi menjadi beberapa kelompok dikarenakan saat kegiatan tersebut terdapat perlombaan antar regu.

\section{Perubahan Sikap Sosial Siswa Setelah Terjadi Proses Pembentukan Sikap Sosial Melalui Metode Pembelajaran IPS Kelas VII di SMP Brawijaya Smart School Malang}

Dengan dibentuknya sikap sosial dalam diri siswa kelas VII SMP Brawijaya Smart School Malang melalui metode pembelajaran IPS serta dibantu dengan daya pendukung yang lain yakni berupa peraturan sekolah, budaya sekolah serta program-program yang terangkum dalam kegiatan-kegiatan ekstrakulikuler yang ada di sekolah meliputi pramuka, bela negara, keputrian, bakti sosial, dan lain sebagainya. Dimana kegiatan-kegiatan tersebut dapat dilakukan melalui metode karya wisata.

Dalam proses perubahan sikap maupun pembentukan sikap ini dipengaruhi oleh 2 (dua) faktor yakni faktor internal (fisiologis dan psikologis), serta faktor eksternal (pengalaman atau situasi yang dihadapi individu, norma-norma yang ada di lingkungan sekitar, dan hambatanhambatan atau pendorong). Dimana semua itu akan berpengaruh langsung dalam diri individu. Akan tetapi faktor individu (intern) mempunyai peranan penting sebagai faktor penentu dikarenakan individulah yang menanggapi dunia luarnya, serta individulah yang mengadakan seleksi mana yang diterima dan ditolak semua yang datang dari luar dirinya (faktor ekstern). Karena itu keduanya bersifat saling mempengaruhi dalam proses perubahan sikap maunpun pembentukan sikap sendiri (Bimo, 2003).

Dari hasil proses pembentukan sikap sosial di kelas VII SMP Brawijaya yang telah 
dipaparkan peneliti secara rinci pada rumusan masalah yang kedua mengenai bagaimana bentukbentuk sikap sosial (jujur, disiplin, tanggung jawab, peduli, santun, percaya diri, toleransi, dan kerjasama) dapat disimpulkan, bahwa hasil dari proses pembentukan sikap sosial siswa kelas VII cenderung baik atau positif. Hal itu dapat terjadi dikarenakan faktor dari luar yang turut mempengaruhi terbentuknya sikap dalam diri siswa yang juga sangat mendukung, baik itu dari norma atau segala peraturan utamanya di sekolah, anggota Tripitaka pendidikan, pengalaman, serta situasi yang ada baik dirumah maupun di sekolah.

Diharapkan dengan adanya pembentukan sikap sosial tersebut dimana wujud akhirnya berupa sebuah perubahan sikap dalam diri siswa dari tidak baik menjadi lebih baik. Hal tersebut yang nantinya yang sangat diharapkan oleh semua anggota Tripitaka Pendidikan yang terdiri dari sekolah (guru), orang tua, serta masyarakat. berikut beberapa perubahan sikap dalam diri siswa kelas VII SMP Brawijaya Smart School Malang, yang diperoleh peneliti dari hasil observasi, wawancara:

Pertama, dari guru IPS dari pihak sekolah khususnya guru IPS yang menjadi informan kedua setelah siswa. Beliau mengaku bahwa terdapat perubahan sikap sosial yang ada dalam diri siswa kelas VII. Ibu Yuli Puji Astuti selaku guru IPS mengaku bahwa terdapat perubahan beberapa sikap sosial (jujur, disiplin, santun, peduli, sikap percaya diri, tanggung jawab, toleransi, dan kerjasama). Selain guru IPS, bapak Muhammad arif selaku Kepala Sekolah juga turut merasakan hal tersebut terutama pada sikap disiplin siswa hal ini dibuktikan dengan kasus keterlambatan siswa yang semakin berkurang. Tidak hanya kepala sekolah dan guru IPS saja, bapak Khoirul Huda selaku Waka Kurikulum juga turut merasakan perubahan tersebut utamanya pada sikap santun hal ini juga dibuktikan dengan seringnya siswa menyapa guru mereka saat bertemu baik di sekolah maupun ketika bertemu diluar sekolah.

Kedua, dari pihak keluarga sendiri mengaku bahwa turut ikut merasakan perubahan sikap sosial pada anaknya tersebut, salah satunya pada sikap disiplin yakni anak sedang mengerjakan PR (Pekerjaan Rumah) dari sekolah ia langsung bergegas mengerjakan bahkan tidak pernah telat untuk mengerjakannya dan juga sangat disiplin dalam beribadah pula. Selain itu anak juga terlihat sangat disiplin dalam berangkat ke sekolah, hal ini di tandai dengan anak berangkat lebih awal ke sekolah sebelum masuk jam sekolah dikarenakan mereka takut terkena hukuman maupun point pengurangan.

Ketiga, pihak masyarakat juga turut merasakan perubahan sikap sosial tersebut hal ini dibuktikan dengan keikutsertaan anak-anak dalam mengikuti kerja bakti serta menjadi anggota karang taruna (perkumpulan remaja) di lingkungan rumah mereka.

\section{KESIMPULAN}

Setelah melakukan penelitian dengan melakukan wawancara, observasi dan dokumentasi dapat diperoleh hasil penelitian mengenai proses pembentukan sikap sosial siswa, bentuk-bentuk sikap sosial siswa dan perubahan sikap sosial siswa setelah terjadi proses pembentukan sikap sosial. Peneliti dapat menarik kesimpulan bahwa:

1. Dalam proses pembentukan sikap sosial melalui metode pembelajaran IPS dapat dilakukan oleh guru IPS dengan baik dan hasil yang baik pula, hal itu juga dikarenakan faktor yang mempengaruhi pembentukan sikap sosial baik dari dalam (individu sendiri) maupun dari luar (norma, lingkungan sekitar, dan lain sebagainya) dapat menjadi daya pendukung yang baik seperti kegiatan ekstrakulikuler (bakti sosial, pramuka, bella negara, dll), budaya sekolah dan peraturan sekolah. Tak lupa juga peran orang tua dirumah yang cukup baik dalam mendukung terbentuknya sikap sosial siswa sendiri.

2. Mengenai bentuk-bentuk sikap sosial (jujur, disiplin, peduli, percaya diri, tanggung jawab, toleransi) tersebut dapat terlihat melalui metode pembelajaran serta kegiatan ekstrakulikuler 
sekolah (bella negara, bakti sosial, pramuka, dll), dimana dalam kegiatan tersebut dapat terlaksana dengan metode karya wisata. Selain melalui kedua hal tersebut, bentuk-bentuk sikap sosial juga dapat terlihat dalam pelaksanaan peraturan-peraturan serta budaya sekolah oleh siswa.

Secara keseluruhan dari beberapa sikap sosial yang sudah tersebut diatas dapat disimpulkan bahwa setelah diadakannya proses pembentukan sikap sosial oleh guru IPS dan dibantu dengan daya pendukung yang lain baik dari pihak sekolah maupun orang tua mereka, sikap sosial yang ada dalam diri siswa mengalami perubahan ke arah yang lebih baik. Dari beberapa sikap sosial siswa yang mengalami perubahan yang paling terlihat yakni pada perubahan sikap santun dan disiplin

\section{UCAPAN TERIMA KASIH}

Penulis mengucapkan terimah kasih yang sebesar-besarnya kepada Jurusan Pendidikan Ilmu Pengetahuan Sosial Fakultas Ilmu Tarbiyah dan keguruan UIN Maulana Malik Ibrahim Malang.

\section{DAFTAR PUSTAKA}

Abdulsyani. (2007). Sosiologi Skematika, Teori, dan Terapan. PT Bumi Aksara.

Ahmadi, A., \& Uhbiyati, N. (1991). Science Education. PT Rineka Cipta.

Ash-Shobur. (2008). Mushaf Al-Qur'an. PT. Karya Toha Putra.

Bimo, W. (2003). Psikologi Sosial Suatu pengantar. CV Andi Offset.

Fatchul, M. (2011). Pendidikan Karakter: Konstruksi Teoritik dan Praktik. Ar-ruzz Media.

Ida Ayu Dewi Virani, Putu Nanci Riastini, \& I Made Suarjana. (2016). Deskripsi Sikap Sosial

Pada Siswa Kelas 4 SDN Panarukan Kecamatan Buleleng AKbupaten Buleleng. Mimbar PGSD Undiksha, 4(1), 1-11. https://doi.org/http://dx.doi.org/10.23887/jjpgsd.v4i2.7699

jppn.com. (2019, December 30). Sepanjang 2019, 153 Anak jadi Korban Fisik dan Bullying. 1. https://www.jpnn.com/news/sepanjang-2019-153-anak-jadi-korban-fisik-dan-bullying

Marhayani, D. A. (2018). Pembentukan Karakter Melalui Pembelajaran Ips. Edunomic Jurnal Pendidikan Ekonomi, 5(2), 67. https://doi.org/10.33603/ejpe.v5i2.261

Moleong Lexy J. (2002). Metodologi Penelitian Kualitatif. Remaja Rosdakarya.

Muchlas, S., \& Hariyanto. (2013). Konsep dan Model pendidikan Karakter. PT. Remaja Rosdakarya.

Natalia, D. (2013). Pembentukan Sikap Sosial Melalui Pembelajaran IPS Pada Siswa Kelas Vii Smp Negeri 3 Palangka Raya. Socius: Pendidikan Dan Pembelajaran Ilmu Pengetahuan Sosial, 50(5). https://doi.org/http://dx.doi.org/10.20527/jurnalsocius.v5i2.3335

Nursid, S. (1984). Metodologi Pengajaran Ilmu Pengetahuan Sosial. Alumni.

Ratnasari, D. A. (2017). Penanaman sikap sosial pada pembelajaran ilmu pengetahuan sosial (ips) pada sdn 1 pulerejo tahun pelajaran 2016 / 2017. INSPIRASI: Jurnal Ilmu-Ilmu Sosial, Vol 14(No 2), 69-76. https://doi.org/http://dx.doi.org/10.29100/insp.v14i2.455

Sari, R. N., \& Resmi, A. C. (2020). Implementasi Pendidikan Karakter dalam Pembentukan Sikap Sosial Kebangsaan Peserta Didik melalui Pembelajaran IPS (Studi Literatur). Ijtimaiya: Journal of Social Science Teaching, 4(2).

http://journal.stainkudus.ac.id/index.php/Ijtimaia

Stephen, T. (2003). Arsitek Jiwa II. Momentum.

Suyanti. (2017). Peran Pembelajaran IPS Dalam Pembentukan Karakter Bangsa. Prosiding Seminar Nasional Pendidik Dan Pengembang Pendidikan Indonesia, 549-552.

Syaiful, S. (2003). Konsep dan Makna Pembelajaran. Alfabeta.

Tiara, S. K., \& Sari, E. Y. (2019). Analisis Teknik Penilaian Sikap Sosial Siswa Dalam Penerapan Kurikulum 2013 Di Sdn 1 Watulimo. EduHumaniora| Jurnal Pendidikan Dasar 
Kampus Cibiru, 11(1), 21. https://doi.org/10.17509/eh.v11i1.11905

Utami, Y., Purnomo, A., \& Salam, R. (2019). Penanaman Sikap Sosial Melalui Pembelajaran Ipspada Siswa SMP Islam Sudirman Ambarawakabupaten Semarang. Sosiolium: Jurnal

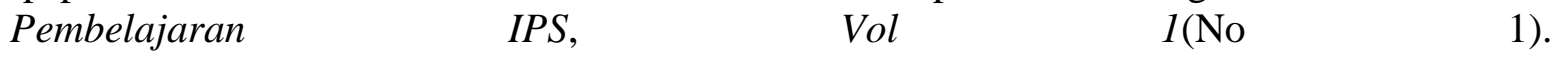
https://journal.unnes.ac.id/sju/index.php/sosiolium/article/view/30446 